\title{
PENGARUH SUSTAINABILITY REPORT TERHADAP KINERJA KEUANGAN PERUSAHAAN
}

\author{
Surya Irma ${ }^{1)}$ dan Nanik Lestari $\left.{ }^{2}\right)^{*}$ \\ ${ }^{1}$ Jurusan Manajemen Bisnis, Politeknik Negeri Batam \\ email: suryairma07@gmail.com \\ ${ }^{2}$ Jurusan Manajemen Bisnis, Politeknik Negeri Batam \\ email: nanik@polibatam.ac.id
}

\begin{abstract}
This study aims to examine the impact of disclosure of sustainability economic (EC), social dimension (SO) and environmental dimension (EN) on issuer's financial performance in 2012-2015 period in mineral and mineral mining sector, energy, gas and petroleum, and infrastructure, and companies that won the SRA (Sustainability report Award) competition in 2015, each winning 1, 2, 3. The research method used in this research is quantitative approach, using cross section data. and it have 40 sample of firm. The independent variables in this study are sustainability reports as measured by economic dimensions (EC), Social (SO), and Environment (EN). The dependent variable in this study is the company's financial performance which can be measured by liquidity ratio, solvability, activity, profitability and investment. Regression used in this research is multiple regression. The result of the research shows that there is influence of sustainability report of economic dimension (EC) with company financial performance. The sustainability report of social dimension and environmental dimension has no effect on company's financial performance. The results of this study are expected to provide benefits to companies, investors, and other stakeholders in the various functions of sustainability reporting mechanisms. The author uses only one control variable are firm size, if adding another control variable, there may be an independent variable influence on the dependent.
\end{abstract}

\section{Keywords: Sustainability report, corporate financial performance, company size}

\begin{abstract}
ABSTRAK
Penelitian ini bertujuan untuk menguji pengaruh pengungkapan sustainability report dimensi ekonomi (EC), dimensi sosial (SO) dan dimensi lingkungan (EN) terhadap kinerja keuangan perusahaan yang terdaftar di BEI periode 2012-2015 dalam sektor pertambangan logam dan mineral, energi, gas dan minyak bumi, manufaktur, dan infrastruktur, serta perusahaan yang memenangkan lomba SRA (Sustainability report Award) tahun 2015 yang berhasil meraih juara 1 , juara 2 , juara 3, berturut-turut. Metode penelitian yang digunakan dalam penelitian ini adalah pendekatan kuantitatif, menggunakan data cross section dan memiliki 40 sampel perusahaan. Variabel independent dalam penelitian ini adalah sustainability report yang diukur dengan dimensi Ekonomi (EC), Sosial (SO), dan Lingkungan (EN). Variabel dependent dalam penelitian ini adalah kinerja keuangan perusahaan yang dapat diukur dengan rasio likuiditas, solvabilittas, aktivitas, provitabilitas dan investasi. Regresi yang digunakan dalam penelitian ini adalah regresi berganda. Hasil penelitian menunjukkan terdapat pengaruh pengungkapan sustainability report dimensi ekonomi (EC) dengan kinerja keuangan perusahaan. Sustainability report dimensi sosial dan dimensi lingkungan tidak berpengaruh terhadap kinerja keuangan perusahaan. Hasil penelitian ini diharapkan dapat memberikan manfaat kepada perusahaan, investor, serta para pemangku kepentingan lainnya dalam beragam fungsi mekanisme pelaporan keberlanjutan. Penulis hanya menggunakan satu variabel kontrol yaitu size perusahaan, jika menambahkan variabel kontrol lainnya kemungkinan terdapat pengaruh variabel independen terhadap dependen.
\end{abstract}

Kata Kunci: Sustainability report, kinerja keuangan perusahaan, size perusahaan

*Corresponding author. E-mail: nanik@polibatam.ac.id 


\section{PENDAHULAN}

Menurut Elkington (1997) sustainability report berarti laporan yang memuat tidak saja informasi kinerja keuangan tetapi juga informasi non keuangan yang terdiri dari informasi aktivitas sosial dan lingkungan yang memungkinkan perusahaan bisa bertumbuh secara berkesinambungan. Sustainability report dapat didefinisikan sebagai laporan yang diterbitkan oleh perusahaan untuk mengungkapkan kinerja perusahaan pada aspek ekonomi, lingkungan dan sosial, serta upaya perusahaan untuk menjadi perusahaan yang akuntabel bagi seluruh pemangku kepentingan (stakeholders) dalam mencapai tujuan kinerja perusahaan menuju pembangunan yang berkelanjutan. Tujuan dari pembuatan sustainability report ini adalah untuk mengungkapkan komitmen dan kinerja ekonomi, lingkungan, dan sosial perusahaan kepada para pemangku kepentingan serta masyarakat luas secara transparan. Melalui sustainability report para stakeholders mendapatkan gambaran yang lebih jelas dan terbuka mengenai segala kegiatan pembangunan berkelanjutan yang telah dilakukan oleh perusahaan.

Implementasi sustainability report di Indonesia didukung oleh sejumlah aturan seperti UU No. 23/1997 tentang manajemen lingkungan dan aturan yang dikeluarkan Bursa Efek Indonesia mengenai prosedur dan persyaratan listing dan serta standar laporan keuangan Pernyataan Standar Akuntansi Keuangan (PSAK) No. 57 yang diterbitkan oleh Ikatan Akuntan Indonesia (IAI) mengenai regulasi akuntansi pertanggungjawaban sosial di Indonesia. Adanya peraturanperatuan tersebut kini banyak perusahaan yang mulai mengungkapkan informasi sosial lingkungannya kepada publik. Pengungkapan praktik sustainability report oleh perusahaan akan memberikan peningkatan nilai perusahaan karena dukungan yang diperoleh dari pemegang saham baik internal maupun eksternal, sehingga mempengaruhi kinerja keuangan perusahaan (KPMG, 2008).

Penelitian mengenai pengaruh pengungkapan sustainability report pernah dilakukan oleh peneliti terdahulu seperti yang dilakukan Carmichael et.al (2013) dan Tarigan dan Semuel (2014). Penelitian Carmichael et.al (2013) meneliti hubungan praktik keberlanjutan dan kinerja keuangan pada perusahaan konstruksi di Australia. Hasilnya mayoritas perusahaan konstruksi di Australia tingkat pelaporannya rendah, sedangkan perusahaan konstruksi yang mengeluarkan laporan non keuangan (sustainability report) sebagian besar mengungguli mereka yang tidak sejumlah rasio keuangan. Penelitian Tarigan dan Semuel (2014) menguji pengungkapan sustainability report dan kinerja keuangan yang membagi dimensi sustainability reporting menjadi tiga, yaitu ekonomi, lingkungan, dan sosial. Hasil penelitian tersebut tidak terdapat pengaruh pengungkapan sustainability report dimensi ekonomi (EC) terhadap kinerja keuangan, namun ada pengaruh pengungkapan sustainability report dimensi lingkungan (EN) dan dimensi sosial (SO) terhadap kinerja keuangan meskipun pengaruhnya negatif.

Dari beberapa penelitian tersebut, maka research gap dari penelitian Carmichael et.al (2013) dan Tarigan dan Semuel (2014) adalah tidak konsistennya hasil penelitian yang dilakukan oleh peneliti-peneliti sebelumnya dari bukti empiris mengenai hubungan sustainability report terhadap kinerja keuangan perusahaan. Penelitian Carmichael et.al (2013) menyimpulkan mayoritas perusahaan konstruksi di Australia yang tidak mengeluarkan sustainability report tingkat pelaporannya rendah, sedangkan perusahaan konstruksi yang mengeluarkan sustainability report sebagian besar mengungguli mereka yang tidak mengeluarkan sustainability report. Sedangkan pada penelitian Tarigan dan 
Semuel (2014) menyimpulkan adanya pengaruh pengungkapan sustainability report dimensi lingkungan (EN) dan dimensi sosial (SO) terhadap kinerja keuangan namun tidak terdapat pengaruh pengungkapan sustainability report dimensi ekonomi (EC).

Jadi, penulis ingin memberikan bukti empiris dari gap riset tersebut dengan menguji apakah ada hubungan sustainability report terhadap kinerja keuangan. Sustainability report diukur dengan indikator Global Reporting Initiative (GRI) G4 tahun 2013 yaitu dimensi Ekonomi-Economics (EC), SosialSocial (SO) dan Lingkungan-Environment (EN). Dimensi ekonomi (EC) yang terdiri dari Kinerja Ekonomi, Keberadaan di Pasar, Dampak Ekonomi Tidak Langsung dan Praktik Pengadaan. Dimensi sosial (SO) terdiri dari Praktik Ketenagakerjaan dan Kenyamanan Bekerja, Hak Asasi Manusia-Human Rights (HR), MasyarakatSociety (SO), dan Tanggung Jawab Produk-Product Responsibility (PR). Dimensi lingkungan (EN) terdiri dari Bahan, Energi, Air, Keanekaragaman Hayati, Emisi, Limbah, Produk dan Jasa, Transportasi, Asesmen Pemasok atas Lingkungan, dan Mekanisme Pengaduan Masalah Lingkungan.

Kinerja keuangan diukur dengan menggunakan 5 rasio kinerja keuangan dari konsep Rahardjo (2007:104) yaitu rasio Likuiditas, Solvabilitas, Aktivitas, Profitabilitas dan Investasi. Kinerja keuangan tersebut diperoleh dari data keuangan perusahaan yang terdaftar di Bursa Efek Indonesia periode 2012 - 2015 (empat tahun).

Perbedaan penelitian ini dengan penelitian sebelumnya, pada penelitian ini sustainability report diukur dengan indikator Global Reporting Initiative (GRI) yang terbaru yaitu G4 tahun 2013, sedangkan di penelitian Carmichael et.al (2013) menggunakan indikator Global Reporting Initiative (GRI) yang lama yaitu tahun 2006 dan penelitian Tarigan dan
Semuel (2014) menggunakan indikator Global Reporting Initiative (GRI) tahun 2011. Pada penelitian ini, penulis mengukur kinerja keuangan dengan menggunakan konsep Rahardjo (2007) yaitu Likuiditas, Solvabilitas, Aktivitas, Profitabilitas dan Investasi. Sedangkan penelitian Carmichael et.al (2013) hanya menggunakan 1 rasio kinerja keuangan yaitu profitability equity valuation serta penelitian Tarigan dan Semuel (2014) menggunakan 5 rasio kinerja keuangan menurut Ross et al. (2003) yaitu manajemen aset, profitabilitas, leverage, likuiditas dan pasar. Sampel di penelitian ini adalah perusahaan non keuangan yang terdiri dari pertambangan logam dan mineral, energi, gas dan minyak bumi, manufaktur, dan infrastuktur yang mempublikasikan sustainability report tahun 2013-2015. Sedangkan penelitian Carmichael et.al (2013) hanya menggunakan sampel perusahaan konstruksi, serta penelitian Tarigan dan Semuel (2014) menggunakan perusahaan manufaktur.

\section{KAJIAN LITERATUR}

Teori pertama yaitu Stakeholder Theory mengatakan bahwa perusahaan bukanlah entitas yang hanya beroperasi untuk kepentingannya sendiri namun harus memberikan manfaat bagi stakeholdernya (Ghazali dan Chariri, 2007). Teori stakeholder berhubungan dengan konsep tanggung jawab sosial perusahaan dimana kelangsungan hidup perusahaan dipengaruhi oleh para stakeholder-nya. Seperti halnya pemegang saham yang mempunyai hak terhadap tindakantindakan yang dilakukan oleh manajemen perusahaan, stakeholder juga mempunyai hak terhadap perusahaan. Teori ini menjelaskan mengenai pentingnya perusahaan untuk memuaskan keinginan para stakeholder. Dalam hal ini, perusahaan mengungkapkan secara sukarela atas investasi lingkungan yang telah dilakukan untuk memberikan nilai tambah serta 
manfaat bagi masyarakat yang merupakan stakeholder-nya.

Teori kedua yaitu Legitimacy Theory, yang mempengaruhi pemikiran laporan berkelanjutan adalah teori legitimasi. Teori legitimasi (Legitimacy theory) berfokus pada interaksi perusahaan dengan masyarakat. Ghozali dan Chariri (2007) menyatakan bahwa hal yang mendasari teori legitimasi adalah kontrak sosial perusahaan dengan masyarakat dimana perusahaan beroperasi dan menggunakan sumber ekonomi. Legitimasi perusahaan akan diperoleh, jika terdapat kesamaan hasil dengan yang diharapkan oleh masyarakat dari perusahaan, sehingga tidak ada tuntuntan dari masyarakat. Kedua teori baik legitimacy theory dan stakeholders theory merupakan teori yang menjelaskan motivasi para manajer atau organisasi untuk melakukan pengungkapan laporan berkelanjutan.

\subsection{Sustainability Report}

Variable independen dalam penelitian ini adalah pengungkapan sustainability report didefinisikan sebagai laporan yang diungkapkan oleh perusahaan yang berkaitan dengan aktivitas sosial yang dilakukan perusahaan yang meliputi dimensi Ekonomi-Economics (EC), SosialSocial (SO) dan Lingkungan-Environment (EN) (GRI-G4 Guideliness). Tiga dimensi yang terdapat dalam pengungkapan sustainability report tersebut terdapat 83 item yang terkandung didalamnya, dimana 83 item tersebut akan disesuaikan pada masing masing perusahaan dengan memberikan skor 1 jika item diungkapkan dan 0 jika tidak diungkapkan itu sebagai penilaiannya. Setelah dilakukan pemberian skor pada seluruh item, skor tersebut kemudian dijumlahkan untuk memperoleh keseluruhan skor untuk setiap perusahaan.

Formula untuk perhitungan indeks skor setiap dimensi adalah sebagai berikut:

$$
\text { Index }=\frac{\mathrm{n}}{\mathrm{k}}
$$

Keterangan:

Index = Index Skor Setiap Dimensi

$\mathrm{n}=$ Jumlah Item yang Diungkapkan Setiap Dimensi

$\mathrm{k}=$ Jumlah Item yang Diharapkan Setiap Dimensi

\subsection{Kinerja Keuangan Perusahaan}

Variabel dependen dalam penelitian ini adalah kinerja keuangan perusahaan yang dapat diukur dengan rasio Likuiditas, Solvabilitas, Aktivitas, Profitabilitas dan Investasi sesuai dengan konsep dari Rahardjo (2007). Nilai dari variabel dependen ini akan didapatkan dari rata-rata setiap rasio keuangan perusahaan yang dijadikan sampel dalam sustainability report.

Menurut Ghozali dan Chariri (2007), kinerja perusahaan dapat diukur dengan menggunakan informasi keuangan atau juga menggunakan informasi non keuangan. Informasi non keuangan ini dapat berupa kepuasan pelanggan atas pelayanan yang diberikan oleh perusahaan. Meskipun begitu, kebanyakan kinerja diukur dengan rasio keuangan dalam periode tertentu.

Menurut Rahardjo (2007) rasio keuangan perusahaan digolongkan menjadi lima kelompok yaitu:

a. Rasio Likuiditas (liquidity ratios) adalah rasio yang menunjukkan kemampuan perusahaan untuk memenuhi kewajiban jangka pendek.

b. Rasio Solvabilitas (laverage ratios) adalah rasio yang menunjukkan kemampuan perusahaan dalam memenuhi kewajiban baik jangka pendek atau jangka panjang.

c. Rasio Aktivitas (activity ratios) adalah rasio yang menunjukkan tingkat efektivitas dalam penggunaan aktiva atau kekayaan (aset) perusahaan.

Sumber: www.globalreporting.org 
d. Rasio Profitabilitas (probability ratios) adalah rasio yang menunjukkan tingkat perolehan keuntungan dibandingkan penjual atau aktiva.

e. Rasio Investasi (investment ratios) adalah rasio yang menunjukkan rasio investasi dalam surat berharga seperti saham dan obligasi.

Perusahaan yang menjadi sampel dalam penelitian ini adalah perusahaan yang dipilih tertentu yang dibagi dalam 4 kategori, yaitu pertambangan logam dan mineral, energi, gas dan minyak bumi, manufaktur berdasarkan metode purposive sampling, yaitu pemilihan sampel sesuai dengan kriteria.

Berdasarkan bukti empiris yang diuraikan di kajian literatur, maka pengungkapan sustainability report dimensi ekonomi berpengaruh terhadap kinerja keuangan. Dalam hal ini, perusahaan yang mengungkapkan sustainability report akan semakin bagus kinerja keuangan perusahaannya. Dimensi ekonomi memberikan indikasi utama bagaimana organisasi/perusahaan telah menciptakan kesejahteraan bagi pemangku kepentingan dan memberikan gambaran tentang profil ekonomi organisasi/perusahaan yang berguna untuk melihat keselarasan dengan indikator kinerja lainnya Global Reporting Initiative (GRI) G4 tahun 2013. Berdasarkan hasil penelitian-penelitian tersebut tersebut maka penulis berasumsi bahwa pengungkapan sustainability report dimensi ekonomi, sosial dan lingkungan berpengaruh dengan kinerja keuangan.

Dengan menggunakan argument tersebut penulis mengajukan hipotesis:

H1: Pengungkapan sustainability report dimensi ekonomi (EC) berpengaruh terhadap kinerja keuangan perusahaan.

$\mathrm{H} 2$ : $\quad$ Pengungkapan sustainability report dimensi sosial berpengaruh terhadap kinerja keuangan perusahaan
H3: Pengungkapan sustainability report dimensi lingkungan berpengaruh terhadap kinerja keuangan perusahaan

\section{METODE PENELITIAN}

Penelitian ini menggunakan populasi semua perusahaan yang terdaftar di Bursa Efek Indonesia selama periode 2012-2015. Adapun kriteria yang digunakan dalam penelitian ini adalah sebagai berikut:

a. Perusahaan yang mempublikasikan laporan keuangan selama tahun 2012-2015;

b. Perusahaan non keuangan yang termasuk ke dalam kategori perusahaan menengah/besar infrastruktur yang mempublikasikan sustainability report tahun 2013-2015;

c. Perusahaan yang memenangkan lomba SRA (Sustainability Report Award) tahun 2015 yang berhasil meraih juara 1 , juara 2, juara 3 , berturut-turut.

Penelitian ini menggunakan data cross section sesuai dengan penelitian sebelumnya, Carmichael et.al (2013) dengan mengumpulkan data keuangan yang terdaftar di Bursa Efek Indonesia (BEI) tanpa memperhatikan ketesediaan tahun pelaporan keuangan. Selain dari cross section, teknik pengumpulan data untuk variabel lainnya yang digunakan adalah teknik arsip basis data untuk memperoleh data sekunder yang diakses melalui situs www.idx.co.id untuk BEI (Bursa Efek Indonesia), dan www.globalreporting.org untuk SR (Sustainability Report).

Data yang diperoleh dalam penelitian ini diolah menggunakan program komputerisasi. Pertama-tama dilakukan tabulasi menggunakan program Microsoft Excel kemudian diolah menggunakan program Statistical Product and Service Solution (SPSS) versi 17 karena program ini memiliki kemampuan analisis statistik 
cukup tinggi, sehingga mudah dipahami cara pengoperasiannya.

\section{HASIL DAN PEMBAHASAN}

Objek penelitian yang digunakan pada penelitian ini adalah semua perusahaan yang terdaftar di Bursa Efek Indonesia yang mempublikasikan laporan keuangan selama tahun 2012-2015, perusahaan non keuangan yang termasuk ke dalam kategori perusahaan menengah/besar yang dibagi dalam 4 kategori, yaitu pertambangan logam dan mineral, energi, gas dan minyak bumi, manufaktur, dan infrastruktur yang mempublikasikan sustainability report tahun 2012-2015, memiliki data yang lengkap terkait dengan variabel-variabel yang digunakan dalam penelitian dan perusahaan yang memenangkan lomba SRA (Sustainability Report Award) tahun 2012-2015 yang berhasil meraih juara 1, juara 2, juara 3, berturut-turut. Sampel yang memenuhi kriteria yang telah ditetapkan adalah sebesar 40. Adapun sampel yang digunakan dalam penelitian ini dapat dilihat pada tabel 1 sebagai berikut:
Tabel 1. Karakteristik Sampel

\begin{tabular}{|c|c|c|c|c|}
\hline Kriteria & 2012 & 2013 & 2014 & 2015 \\
\hline $\begin{array}{l}\text { Perusahaan yang terdaftar di } \\
\text { Bursa Efek Indonesia dan } \\
\text { menampilkan laporan kinerja } \\
\text { keuangan perusahaan periode } \\
2012-2015\end{array}$ & 491 & 489 & 509 & 532 \\
\hline $\begin{array}{l}\begin{array}{l}\text { Perusahaan yang tidak } \\
\text { menampilkan } \\
\text { sustainability report }\end{array} \\
\text { data }\end{array}$ & $(460)$ & $(460)$ & (449) & (495) \\
\hline $\begin{array}{l}\text { Perusahaan } \quad \text { yang } \\
\text { mengungkapkan } \\
\text { report 2012-2015 }\end{array}$ & 31 & 29 & 60 & 37 \\
\hline $\begin{array}{l}\text { Perusahaan } \\
\text { memenangkan lomba SRA } \\
\text { (Sustainability Report Award) } \\
\text { tahun 2012-2015 berturut-turut }\end{array}$ & (21) & (19) & $(50)$ & (27) \\
\hline $\begin{array}{l}\text { Perusahaan non keuangan yang } \\
\text { termasuk ke dalam kategori } \\
\text { perusahaan menengah/besar } \\
\text { yang dibagi dalam } 4 \text { kategori, } \\
\text { yaitu pertambangan logam dan } \\
\text { mineral, energi, gas dan minyak } \\
\text { bumi, manufaktur, infrastruktur } \\
\text { yang mempublikasikan } \\
\text { sustainability report tahun } \\
\text { 2012-2015 dan perusahaan } \\
\text { memenangkan lomba SRA } \\
\text { (Sustainability Report Award) } \\
\text { tahun 2015 yang berhasil } \\
\text { meraih juara 1, juara 2, juara 3, } \\
\text { berturut-turut. }\end{array}$ & 10 & 10 & 10 & 10 \\
\hline $\begin{array}{l}\text { Total sampel yang digunakan } \\
\text { selama } 4 \text { tahun pengamatan } \\
\text { Total keseluruhan sampel }\end{array}$ & 10 & 10 & 10 & 10 \\
\hline
\end{tabular}

Sumber: Data diolah, 2017

Hasil statistik deskriptif dalam penelitian ini penulis menggunakan software SPSS versi 17.00, dengan menggunakan statistik deskriptif dan frekuensi. Yang diihat dari statistik deskriptif adalah nilai minimum, maximum, rata-rata, dan standar deviasi. Dalam penelitian ini, variabel dependen yang digunakan adalah kinerja keuangan perusahaan yang dapat diukur dengan rasio Likuiditas, Solvabilitas, Aktivitas, Profitabilitas, sedangkan variabel independen yang digunakan adalah sustainability report yang diukur dengan dimensi Ekonomi (EC), Sosial (SO) dan Lingkungan (EN). Berikut tabel 2 hasil statistic deskriptif yang diolah menggunakan SPSS dengan melihat nilai minimum, maximum, rata-rata, dan standar deviasi. 
Tabel 2. Hasil Analisis Statistik Deskriptif

\begin{tabular}{|l|c|c|c|c|c|}
\hline \multicolumn{5}{|c|}{ Descriptive Statistics } \\
\hline Variabel & $\mathbf{N}$ & Min & Max & Mean & $\begin{array}{c}\text { Std. } \\
\text { Deviation }\end{array}$ \\
\hline Ekonomi & 40 & 0.00 & 0.85 & 0.371 & 0.286 \\
\hline Lingkungan & 40 & 0.00 & 1.03 & 0.403 & 0.331 \\
\hline Sosial & 40 & 0.00 & 0.85 & 0.349 & 0.294 \\
\hline Size & 40 & 19.95 & 33.13 & 28.489 & 4.689 \\
\hline Current ratio & 40 & 0.26 & 7.75 & 1.909 & 1.590 \\
\hline $\begin{array}{l}\text { Inventory } \\
\text { turn over }\end{array}$ & 40 & 3.96 & 224.34 & 24.894 & 38.679 \\
\hline $\begin{array}{l}\text { Asset turn } \\
\text { over }\end{array}$ & 40 & 0.03 & 2.61 & 0.921 & 0.623 \\
\hline ROA & 40 & 0.06 & 2.16 & 0.726 & 0.478 \\
\hline ROE & 40 & 0.05 & 19.79 & 5.579 & 4.869 \\
\hline $\begin{array}{l}\text { Gross profit } \\
\text { margin }\end{array}$ & 40 & 0.02 & 6.80 & 0.417 & 1.047 \\
\hline $\begin{array}{l}\text { Net profit } \\
\text { margin }\end{array}$ & 40 & 0.03 & 2.84 & 0.303 & 0.600 \\
\hline ROI & 40 & 0.01 & 7.80 & 1.326 & 1.405 \\
\hline
\end{tabular}

Sumber: Data diolah, 2017

Berdasarkan hasil statistik deskriptif tersebut pada tabel 2 dapat disimpulkan bahwa pengungkapan dari 3 dimensi sustainability report (ekonomi, lingkungan dan sosial) yang cukup tinggi intensitasnya diperoleh pada dimensi lingkungan. Hal ini diartikan, berdasarkan data sampel yang ada bahwa komponen yang paling lengkap atas data dan informasi atas sustainability report dari ketiga variabel independen adalah dimensi lingkungan. Ukuran perusahaan yang diukur dengan size (total aset) memiliki variasi yang cukup tinggi, dengan nilai minimum 19.95 dan nilai maksimum 33.13 dengan nilai mean 28.489, yang berarti bahwa perusahaan sampel kebanyakan memiliki total aset yang rendah. Rasio likuiditas yang diproksikan dengan current ratio menunjukkan rentang nilai yang cukup tinggi dengan nilai minimum 0.26 dan nilai maksimum 7.75 dengan nilai mean 1.909, yang menunjukkan bahwa kebanyakan perusahaan sampel memiliki rasio likuiditas yang rendah. Begitu pula dengan nilai solvabilitas yang diproksikan dengan rasio return on equity ( $R O E$ ) nilainya memiliki variasi yang cukup tinggi, dengan nilai minimum 0.05 dan nilai maksimum 19.79 dengan mean 5.579, yang berarti bahwa perusahaan sampel kebanyakan memiliki rasio solvabilitas rendah. Inventory turnover yang merupakan pengukuran untuk aktiva yang menunjukkan rentang nilai yang cukup tinggi dengan nilai minimum 3.96 dan nilai maksimum 224.34 dengan nilai mean 24.894, yang menunjukkan bahwa kebanyakan perusahaan sampel memliki rasio aktiva yang rendah.

Pada penelitian ini penulis menggunakan uji $\mathrm{t}$ yang dilakukan untuk menguji seberapa jauh satu variabel independen secara individual dapat menerangkan variabel dependen. Hasil uji $t$ dalam penelitian ini digunakan untuk pengujian hipotesis pada model regresi. Penulis mengajukan tiga hipotesis yang akan diuji. Jumlah sampel dalam penelitian ini adalah 40. Penulis melakukan pengolahan data menggunakan software SPSS 17.

Pengungkapan sustainability report dimensi ekonomi (EC) berpengaruh terhadap kinerja keuangan perusahaan

Hipotesis pertama menyatakan bahwa pengungkapan sustainability report dimensi ekonomi (EC) berpengaruh terhadap kinerja keuangan perusahaan yang diukur dengan current ratio, inventory turnover, asset turn over, ROA, ROE, gross profit margin, net profit margin, ROI. Penelitian ini menggunakan 40 sampel yang diolah dengan menggunakan SPSS dan hasilnya disajikan dalam tabel 3 .

Berdasarkan tabel 3, hipotesis pertama menyatakan bahwa pengungkapan sustainability report dimensi ekonomi (EC) berpengaruh terhadap kinerja keuangan perusahaan yang diukur dengan current ratio, inventory turn over, asset turn over, ROA, ROE, gross profit margin, net profit margin, $R O I$, namun tidak mempengaruhi current ratio, inventory turn over, ROA, 
ROE, gross profit margin, net profit margin, ROI, tetapi ekonomi hanya mempengaruhi asset turn over. Hal ini dapat dilihat dari nilai signifikansi pengaruh dimensi ekonomi terhadap current ratio sebesar 0.114 , pengaruh dimensi ekonomi terhadap inventory turn over sebesar 0.282, pengaruh dimensi ekonomi terhadap ROA sebesar 0.540, pengaruh dimensi ekonomi terhadap $R O E$ sebesar 0.640 , pengaruh dimensi ekonomi terhadap gross profit margin sebesar 0.400 , pengaruh dimensi ekonomi terhadap net profit margin sebesar 0.887 , pengaruh dimensi ekonomi terhadap ROI sebesar 0.420. Pengaruh pengungkapan sustainability report dimensi ekonomi terhadap asset turn over, dapat diterima pada tingkat signifikansi $10 \%$ yang dilihat dari nilai Sig. 0.081.

Tabel 3. Hasil Pengujian Pengaruh Sustainability Report terhadap kinerja keuangan perusahaan

\begin{tabular}{|c|c|c|c|}
\hline $\begin{array}{l}\text { Variabel } \\
\text { Dependen }\end{array}$ & Coefficient & $t$-Statistic & Sig. \\
\hline current ratio & -0.404 & -1.372 & 0.179 \\
\hline $\begin{array}{l}\text { inventory turn } \\
\text { over }\end{array}$ & -0.404 & -0.964 & 0.342 \\
\hline Asset turn over & -0.211 & -0.687 & 0.497 \\
\hline ROA & -0.322 & -1.006 & 0.321 \\
\hline ROE & -0.174 & -0.555 & 0.582 \\
\hline $\begin{array}{l}\text { Gross } \\
\text { margin }\end{array}$ & 0.193 & 0.603 & 0.550 \\
\hline Net profit margin & -0.264 & -0.806 & 0.426 \\
\hline ROI & -0.111 & -0.337 & 0.738 \\
\hline
\end{tabular}

Sumber: Data diolah, 2017

\section{Pengungkapan sustainability report dimensi lingkungan (EN) berpengaruh terhadap kinerja keuangan perusahaan}

Hipotesis kedua menyatakan bahwa pengungkapan sustainability report dimensi lingkungan (EN) berpengaruh terhadap kinerja keuangan perusahaan yang diukur dengan current ratio, inventory turnover, asset turn over, ROA, ROE, gross profit margin, net profit margin, ROI.
Penelitian ini menggunakan 40 sampel yang diolah dengan menggunakan SPSS dan hasilnya disajikan dalam tabel 4 .

Tabel 4. Hasil Pengujian Pengaruh Sustainability Report (lingkungan) terhadap kinerja keuangan perusahaan

\begin{tabular}{|l|l|l|l|}
\hline $\begin{array}{l}\text { Variabel } \\
\text { Dependen }\end{array}$ & Coefficient & t-Statistic & Sig. \\
\hline $\begin{array}{l}\text { current ratio } \\
\text { inventory turn } \\
\text { over }\end{array}$ & 0.795 & 2.559 & 0.114 \\
\hline $\begin{array}{l}\text { assetnturn over } \\
\text { ROA }\end{array}$ & 0.574 & 1.092 & 0.282 \\
\hline ROE & -0.205 & 1.798 & $0.081 *$ \\
\hline $\begin{array}{l}\text { grossnprofit } \\
\text { margin }\end{array}$ & 0.649 & -0.618 & 0.540 \\
\hline nethprofit margin & -0.283 & 1.994 & 0.640 \\
\hline ROI & -0.280 & -0.852 & 0.400 \\
\hline
\end{tabular}

Sumber: Data diolah, 2017

Berdasarkan tabel 4, hipotesis kedua menyatakan bahwa pengungkapan sustainability report dimensi lingkungan (EN) berpengaruh terhadap kinerja keuangan perusahaan yang diukur dengan current ratio, inventory turn over, asset turn over, ROA, ROE, gross profit margin, net profit margin, ROI, namun tidak mempengaruhi kinerja keuangan yang diukur dengan current ratio, inventory turn over, asset turnover, ROA, ROE, gross profit margin, net profit margin, ROI. Hal ini dapat dilihat dari nilai signifikansi pengaruh dimensi lingkungan terhadap current ratio sebesar 0.179 , pengaruh dimensi lingkungan terhadap inventory turnover sebesar 0.342 , pengaruh dimensi lingkungan terhadap asset turn over sebesar 0.497, pengaruh dimensi lingkungan terhadap $R O A$ sebesar 0.321 , pengaruh dimensi lingkungan terhadap $R O E$ sebesar 0.582, pengaruh dimensi lingkungan terhadap gross profit margin sebesar 0.550 , pengaruh dimensi lingkungan terhadap net profit margin sebesar 0.426 , pengaruh dimensi lingkungan terhadap $R O I$ sebesar 0.738 . 


\section{Pengungkapan sustainability report dimensi sosial (SO) berpengaruh terhadap kinerja keuangan perusahaan}

Hipotesis ketiga menyatakan bahwa pengungkapan sustainability report dimensi sosial (SO) berpengaruh terhadap kinerja keuangan perusahaan yang diukur dengan current ratio, inventory turn over, asset turn over, ROA, ROE, gross profit margin, net profit margin, ROI. Penelitian ini menggunakan 40 sampel yang diolah dengan menggunakan SPSS dan hasilnya disajikan dalam tabel 5 .

Tabel 5. Hasil Pengujian Pengaruh Sustainability Report (sosial) terhadap kinerja keuangan perusahaan

\begin{tabular}{|l|l|l|l|}
\hline Variabel Dependen & Coefficient & t-Statistic & Sig. \\
\hline current ratio & -0.388 & -1.087 & 0.285 \\
\hline inventory turnover & -0.388 & 1.153 & 0.257 \\
\hline Asset turnover & -0.067 & -0.181 & 0.858 \\
\hline ROA & 0.287 & 0.742 & 0.463 \\
\hline ROE & -0.254 & -0.669 & 0.508 \\
\hline Gross profit margin & -0.134 & -0.347 & 0.731 \\
\hline Net profit margin & 0.118 & -0.300 & 0.766 \\
\hline ROI & 0.437 & 1.092 & 0.282 \\
\hline
\end{tabular}

Sumber: Data diolah, 2017

Berdasarkan tabel 5, hipotesis ketiga menyatakan bahwa pengungkapan sustainability report dimensi sosial (SO) berpengaruh terhadap kinerja keuangan perusahaan yang diukur dengan current ratio, inventory turn over, asset turn over, ROA, ROE, gross profit margin, net profit margin, ROI, namun tidak mempengaruhi kinerja keuangan yang diukur dengan current ratio, inventory turn over, asset turn over, ROA, ROE, gross profit margin, net profit margin, ROI. Hal ini dapat dilihat dari nilai signifikansi pengaruh dimensi sosial terhadap current ratio sebesar 0.285 , pengaruh dimensi sosial terhadap inventory turn over sebesar 0.257 , pengaruh dimensi sosial terhadap asset turn over sebesar 0.858 , pengaruh dimensi sosial terhadap $R O A$ sebesar 0.463 , pengaruh dimensi sosial terhadap ROE sebesar 0.508, pengaruh dimensi sosial terhadap gross profit margin sebesar 0.731 , pengaruh dimensi sosial terhadap net profit margin sebesar 0.766 , pengaruh dimensi sosial terhadap ROI sebesar 0.282 .

\section{Analisis Data}

Berdasarkan hasil uji hipotesis antara variabel independen dan variabel dependen yaitu sustainability report dimensi ekonomi, dimensi lingkungan dan dimensi sosial sebagai variabel independen dan kinerja keuangan perusahaan yang diukur dengan rasio likuiditas (current ratio), rasio aktivitas (inventory turn over dan asset turn over), rasio solvabilitas (ROA dan ROE), rasio profitabilitas (gross profit margin dan net profit margin), rasio investasi (ROI). Ringkasan hasil uji statistik dapat dilihat pada tabel 6 sebagai berikut:

Tabel 6. Ringkasan Hasil Uji Hipotesis

\begin{tabular}{|l|l|l|}
\hline H1 & $\begin{array}{l}\text { Hengungkapan sustainability } \\
\text { report dimensi ekonomi (EC) } \\
\text { berpengaruh terhadap kinerja } \\
\text { keuangan perusahaan }\end{array}$ & Terdukung \\
\hline H2 & $\begin{array}{l}\text { Pengungkapan sustainability } \\
\text { report dimensi lingkungan (EN) } \\
\text { berpengaruh terhadap kinerja } \\
\text { keuangan perusahaan }\end{array}$ & Tidak Terdukung \\
\hline H3 & $\begin{array}{l}\text { Pengungkapan sustainability } \\
\text { report dimensi sosial (SO) } \\
\text { berpengaruh terhadap kinerja } \\
\text { keuangan perusahaan }\end{array}$ & Tidak Terdukung \\
\hline
\end{tabular}

Sumber: Data diolah, 2017

Berdasarkan hasil uji hipotesis yang telah dijelaskan pada tabel 6 menunjukkan terdapat pengaruh pengungkapan sustainability report dimensi ekonomi (EC) dengan kinerja keuangan perusahaan yang diukur dengan rasio aktivitas (asset turn over) dengan nilai signifikansi $0.081<$ 0.10 . Hal ini menyatakan bahwa hipotesis (H1) terdukung. Hasil ini tidak sesuai dengan penelitian Burhan dan Rahmanti (2009) yang menyatakan bahwa pengungkapan dimensi ekonomi tidak berpengaruh terhadap kinerja perusahaan. Sama halnya dengan penelitian Tarigan dan Semuel (2014) dalam penelitiannya menemukan tidak terdapat pengaruh 
pengungkapan sustainability report dimensi ekonomi (EC) dengan kinerja keuangan.

Berdasarkan hasil uji hipotesis yang telah dijelaskan pada tabel 6 menunjukkan tidak terdapat pengaruh pengungkapan sustainability report dimensi lingkungan (EN) terhadap kinerja keuangan perusahaan. Hal ini menyatakan bahwa hipotesis (H2) tidak terdukung. Hasil ini sesuai dengan penelitian Burhan dan Rahmanti (2009) yang menyatakan bahwa pengungkapan sustainability report dimensi lingkungan tidak mempengaruhi secara signifikan kinerja keuangan perusahaan. Hasil ini tidak konsisten dengan penelitian Adhima (2011) menyatakan bahwa pengungkapan environmental performance memberikan pengaruh positif terhadap kinerja keuangan perusahaan yang dapat meningkatkan profitabilitas perusahaan.

Berdasarkan hasil uji hipotesis yang telah dijelaskan pada tabel 6 menunjukkan tidak terdapat pengaruh pengungkapan sustainability report dimensi sosial (SO) terhadap kinerja keuangan perusahaan. Hal ini menyatakan bahwa hipotesis (H3) tidak terdukung. Hasil ini tidak sesuai dengan penelitian Burhan dan Rahmanti (2009) dan Rahajeng (2010) yang menyatakan bahwa pengungkapan sustainability report dimensi sosial berpengaruh positif terhadap kinerja keuangan perusahaan. Rasio likuiditas berpengaruh pada luas pengungkapan sukarela. Kondisi perusahaan didasarkan pada alasan bahwa bagi perusahaan yang memiliki likuiditas baik, menunjukkan memiliki struktur finansial yang baik pula (Rahajeng, 2010). Hasil ini tidak konsisten dengan penelitian Adhima (2011) dan Susanto dan Tarigan (2013) yang menyatakan bahwa pengungkapan kinerja sosial masyarakat berpengaruh negatif terhadap kinerja keuangan perusahaan. Artinya, sustainability report dimensi sosial memberikan pengaruh negatif ke perusahaan, dimana pengungkapan sustainability report dimensi sosial dianggap sebagai beban perusahaan yang dapat mengurangi profitabilitas perusahaan

\section{KESIMPULAN DAN SARAN}

Berdasarkan hasil penelitian mengenai pengaruh sustainability report dimensi ekonomi, sosial dan lingkungan terhadap kinerja keuangan perusahaan yang terdaftar di Bursa Efek Indonesia (BEI) periode 2012-2015. Penulis dapat mengambil kesimpulan sebagai berikut:

a. Sustainability report dimensi ekonomi berpengaruh terhadap kinerja keuangan perusahaan.

b. Sustainability report dimensi sosial tidak berpengaruh terhadap kinerja keuangan perusahaan.

c. Sustainability report dimensi lingkungan tidak berpengaruh terhadap kinerja keuangan perusahaan.

Penulis menemukan beberapa keterbatasan dalam penelitian ini. Beberapa keterbatasan tersebut antara lain: Pertama, penelitian ini hanya terbatas pada perusahaan dalam bidang non keuangan yang termasuk ke dalam kategori perusahaan menengah/besar yang dibagi dalam 4 kategori, yaitu pertambangan logam dan mineral, energi, gas dan minyak bumi, manufaktur, dan infrastruktur. Kedua, periode penelitian ini hanya empat tahun yaitu dari tahun 20122015. Ketiga, penulis hanya menggunakan satu variabel kontrol yaitu size perusahaan, jika menambahkan variabel kontrol lainnya kemungkinan terdapat pengaruh variabel independen terhadap dependen.

Penelitian selanjutnya sebaiknya menambah jumlah sampel penelitian, dengan menggunakan seluruh populasi perusahaan dalam bidang keuangan dan non keuangan di Indonesia, dan diharapkan menambah variabel kontrol, jika menambahkan variabel kontrol lainnya kemungkinan terdapat pengaruh variabel independen terhadap dependen. 


\section{DAFTAR PUSTAKA}

Adhima, M. F. (2011). Pengaruh Pengungkapan Sustainability Report Terhadap Profitabilitas Perusahaan Studi Kasus pada Perusahaan Manufaktur yang Terdaftar Dalam Bursa Efek Indonesia. Jurnal Akuntansi dan Keuangan.

Burhan, A. a. (2012). The Impact of Sustainability reporting on Company Performance. Journal of Economics, Business, and Accountancy Ventura, Vol 15, No. 2, pp. 257272.

Carmichael et.al. (2013). The relationship between sustainability practices and financial performance of construction companies. Smart and sustainable built environment, 2(1).

Chariri, A. \& Ghozali I. (2007). Teori Akuntansi. Semarang: Badan Penerbit Univesitas Diponegoro.

Dian. (2015). Sustainability Report Terhadap Kinerja Keuangan dan Pasar. Jurnal Ilmu dan Riset Akuntansi, vol.4, no.4.

Elkington, J. (1997). Cannibals with Forks: The Triple Bottom Line of $21 \mathrm{st}$ Century Business. Capstone: Oxford.

Ernst \& Young Global Limited. (2013). Value of Sustainability Reporting. Boston: Ernst \& Young LLP and the Boston College Center for Corporate Citizenship.

Global Reporting Initiative. (2013). Sustainability Reporting Guidelines 4.

Harahap. (2008). Analisis Kinerja Keuangan. Pekanbaru: Media Akuntansi.

Kasmir. (2008). Manajemen Akuntansi Perusahaan. Surabaya: Pena gagas
Mamduh, M. H. (2009). Analisis Laporan Keuangan. Yogyakarta: AMPYKPN.

Ovi. (2016). Dampak Pengungkapan Sustainability Report Terhadap Kinerja Keuangan dan Kinerja Pasar. Jurnal Ilmu dan Riset Akuntansi, vol.5,no.5.

KPMG International Cooperative. (2008). Sustainability Reporting: A Guide. Retrieved from www.group 100.com.au/publications/ kpmg g100 SustainabilityRep20 0805.pdf

Pratiwi, R. d. (2014). Dampak Sustainability Report Terhadap Kinerja Keuangan dan Risko Perusahaan (Studi Empiris Perusahaan yang Masuk Ke SRIKEHATI Tahun 2009-2010). Jurnal Dinamika Akuntansi, 6(2): 153-157.

Rahardjo, B. (2007). Akuntansi dan Keuangan untuk Manajer Non Keuangan. Bandung: Yrama widya.

Rita, W. (2015). Pengaruh Pengungkapan Sustainability Report Terhadap Kinerja Keuangan Perusahaan.

Ross, S. W. (2003). Fundamental of corporate finance (6th ed.). Singapore: McGraw-Hill Book Company.

Tarigan, J. (2014). Pengaruh Sustainability Reporting terhadap Kinerja Keuangan Perusahaan Publik dari Sisi Profitability Ratio. Business Accounting, Review, Vol. 2, No, 2, No.1.

Undang-undang No. 9 Tahun 1995 Tentang Usaha Menengah/ Besar. 